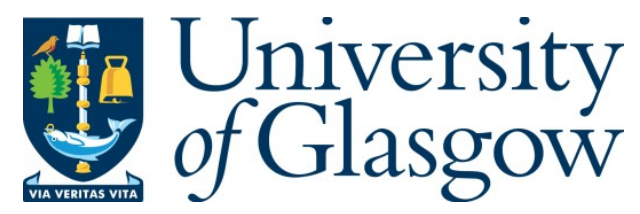

Pedeliento, G., Andreini, D. and Veloutsou, C. (2020) Brand community integration, participation and commitment: a comparison between consumer-run and companymanaged communities. Journal of Business Research, 119, pp. 481-494.

(doi: 10.1016/j.jbusres.2019.10.069)

This is the Author Accepted Manuscript.

There may be differences between this version and the published version. You are advised to consult the publisher's version if you wish to cite from it.

https://eprints.gla.ac.uk/201828/

Deposited on: 28 October 2019

Enlighten - Research publications by members of the University of Glasgow http://eprints.gla.ac.uk 


\title{
Brand Community Integration, Participation and Commitment: A Comparison between Consumer-Run and Company-Managed Communities
}

\author{
Giuseppe Pedeliento ${ }^{1 *}$, Daniela Andreini ${ }^{2}$, Cleopatra Veloutsou ${ }^{3}$
}

Accepted for Publication 26 October 2019

Journal of Business Research

\footnotetext{
* Corresponding author

${ }^{1}$ Department of Management, Economics and Quantitative Methods, University of Bergamo, Via dei Caniana 2 , 24127, Bergamo (Italy), giuseppe.pedeliento@unibg.it, Tel. +39. 0352052678.

2 Department of Management, Economics and Quantitative Methods, University of Bergamo, daniela.andreini@unibg.it.

${ }^{3}$ Adam Smith Business School, University of Glasgow, cleopatra.veloutsou@glasgow.ac.uk.
} 


\title{
Brand Community Integration, Participation and Commitment: A Comparison between Consumer-Run and Company-Managed Communities
}

\begin{abstract}
In the past two decades there has been a growth in the rate at which consumers join, companies use, and researchers study brand communities. Given the expansion of brand communities, scholars insistently analyze why individuals join and stay in them. However, no study concurrently examines the links among the members' integration, participation and commitment to a brand community. Furthermore, research conceive brand communities as homogenous. Whether the feelings and behaviors of members of different kinds of communities, and specifically consumer-run and company-managed brand communities, are comparable is unknown. Using a sample of 2,167 consumers of a leading motorcycle brand, this study examines the members' integration, participation and commitment to consumer-run and company-managed communities. The findings reveal that consumer-run communities stimulate higher levels of integration, participation and commitment than the companymanaged communities, but that the mechanisms connecting integration, participation and commitment are invariant across the two types of community.
\end{abstract}

Keywords: brand communities; consumer-run brand community; company-managed brand community; brand community integration; brand community participation; brand community commitment. 


\section{Introduction}

There is growing evidence that consumers who admire brands increasingly join brand communities. Brand communities are defined as specialized, non-geographically-bound groups, brought together by a structured set of social relations among people who self-select to join them because they have the same feelings towards a brand and accept and recognize bonds with each other and the brand (Muñiz \& O'Guinn, 2001; Veloutsou \& Moutinho, 2009). Members may or may not own the brand (Kumar \& Kumar Nayak, 2019). The introduction, spread, and growth of brand communities in contemporary markets is one of the most influential developments in brand management practices over the past 20 years (Veloutsou \& Guzmán, 2017). Brand communities take an active part in the (co)creation of brand meanings (Cova, Pace \& Skålén, 2015; Skålén, Pace, \& Cova 2015; Black \& Veloutsou, 2017) and may interact via any means that allows their relationships, encompassing online, offline or both online and offline settings. Consumers' membership of a brand community is reported to bring a wide array of benefits for firms, including loyalty, trust, advocacy, increased purchase intention, higher sales, and better access to insights to improve product innovation (Bagozzi \& Dholakia, 2006; Füller, Matzler, \& Hoppe, 2008; Madupu \& Cooley, 2010; Gruner, Homburg, \& Lukas, 2014; Manchanda, Packard \& Pattabhiramaiah, 2015; Coelhoa, Rita, \& Raposo Santos, 2018). Therefore, it is not surprising that marketers and brand managers have put the establishment and the commercial exploitation of brand communities at the top of their priorities (Veloutsou \& Guzmán, 2017). The initiative to begin a brand community may start from companies or from consumers, while brand communities may run with or without involvement of the companies behind the brand in moderating conversations, organizing events or in any other active role in the community's life (Dholakia \& Vianello, 2011). Previous studies suggest that company- 
managed and consumer-run brand communities have differences (Dholakia \& Vianello, 2011; Lee, Kim, \& Kim, 2011; 2012). Company-managed brand communities are established by marketers on behalf of the brand, are often run by managers to foster relationships with current and potential consumers of the brand (Bonnemaizon, Cova, \& Louyot, 2007; Sung, Kim, Kwon, \& Moon, 2010), are a viable tool of relationship marketing (Fournier \& Lee, 2009), and are largely seen as motivated by profit-making purposes (Manchanda et al., 2015). Although the degree of involvement of the managers in the community may vary (Fournier \& Lee, 2009), company-managed brand communities may discourage individual participation because of the individuals' need for self-preservation and privacy related to these commercial settings (Pasternak, Veloutsou, \& Morgan-Thomas, 2017). Consumer-run brand communities are groupings interested in exchanging information and in building and maintaining relationships with other peers sharing the same interest in the brand (Jang et al., 2008; Lee et al., 2012). Conversely, consumer-run brand communities are not risk-free because they bear the threat that community members may transmit brand information in a way not desired by the company (Felix, 2012). These two different types of brand communities are not mutually exclusive: there are, in fact, several brands that have both a company-managed and one or more consumer-run communities, such as Lego (Antorini, Muñiz, \& Askildsen, 2012), Nikon (Dholakia \& Vianello, 2011), Harley Davidson (Schouten \& McAlexander, 1995; Schembri, 2009) and SAP (Quint, 2013).

Regardless of who initiates and who manages a brand community, research agrees that, like any other group of individuals that gather together for a purpose, brand communities are first and foremost social structures (Mathwick, Wiertz, \& Ruyter, 2008) that exist because people that join them participate in their continuance over time (Algesheimer, Dholakia, \& Herrmann, 2005; Casaló, Flavian, \& Guinaliu, 2007; Galehbakhtiari \& Pouryasouri, 2015; Manchanda et al., 2015). Brand community participation can assume different forms ranging 
from more passive behaviors - like reading others' comments - to more active ones - like taking part in brand fests and even being involved in the creation and management of the social life that takes place in the brand community (Lampe, Wash, Velasquez, \& Ozkaya, 2010; Nambisan \& Baron, 2010; Sun, Pei-Luen Rau \& Ma, 2014; Malinen, 2015).

Due to the importance of brand community participation in determining the existence of brand communities, it is not surprising that scholars have repeatedly analyzed what induces consumers to join and remain in brand communities (Madupu \& Colley, 2010;

Galehbakhtiari \& Pouryasouri, 2015). Participation in and support for a brand community cannot be imposed; rather, they are intentional, voluntary actions characterized by different levels of involvement (Muñiz \& O’Guinn, 2001; Fournier \& Lee, 2009; Veloutsou \& Black, 2019). Brand community integration (McAlexander, Schouten, \& Koenig, 2002,

McAlexander, Kim, \& Roberts, 2003) is demonstrated by group processes, strong social ties (Malinen, 2015) and the members' feeling of we-ness or belonging to the brand community (Johnson \& Lowe, 2015) which motivates consumers' willingness to stay in the community and to keep it alive in the long run (Casaló et al., 2007; Zhou, Zhang, \& Zhou, 2012; Liao, Huang, \& Xiao, 2017).

Brands that can count on communities where members have strong feelings of integration enjoy many benefits, such as higher customer satisfaction (McAlexander et al., 2002; Judson, Devasagayam, \& Buff, 2014; Clark, Black, \& Judson, 2017), enhanced brand (Stokburger Sauer, 2010; Millán \& Díaz, 2014) and organizational identification (Rosenbaum \& Martin, 2012), greater loyalty (McAlexander et al., 2002; Madupu \& Cooley, 2010; Millán \& Díaz, 2014; Martin et al., 2015; Kim \& Lee, 2019), higher brand equity (Chou, 2014), enhanced purchase intention (McAlexander et al., 2002; Rosenbaum \& Martin, 2012; Warren \& Brownlee, 2013; Kim \& Lee, 2019) and higher consumers' willingness to brand patronage (Rosenbaum \& Martin, 2012). 
There are several important issues in relation to brand community membership behavior that have not yet been well investigated. Although scholars are concordant that brand community integration is paramount for brand community participation, the literature to date does not offer empirical evidence linking brand community participation with the long-lasting commitment of its members, and in particular brand community commitment (Hook, Baxter, \& Kulczynsk, 2018; Kamboj \& Rahman, 2017). The motives that prompt individuals to participate, brand community participation itself, and individuals' willingness to sustain a brand community, are also under-investigated. Specifically, although scholars have shown that brand communities which combine an online with an offline presence that permit members to engage in both virtual and face-to-face relationships (Black \& Veloutsou, 2017; Lin, Wang, Chang, \& Lina, 2018) are more likely to enhance members' feelings of integration in the brand community (Warren \& Brownlee, 2013), no research has to date examined whether the determinants and outcomes of brand community participation do vary depending on who initiates and manages the community. This is of importance for managers, who see all brand communities, and particularly the brand communities that they initiate and manage, as a powerful brand engagement tool.

In regard to the research gaps, this paper has three different but interrelated aims and a relevant context in which to pursue them. The first is to examine whether integration in a brand community is a driver of brand community participation and brand community commitment. The second is to test whether integration in a brand community is differently formed depending on whether the community is run by consumers or by marketers. The third is to investigate whether the same process can support the development of brand community commitment regardless of the fact that the community is run by consumers or marketers. Two brand communities formed around a well-known motorcycle brand (Moto Guzzi), one 
established and run by consumers (Moto Guzzi World Club) and one established and run by the company (The Clan), were chosen as a research setting.

The rest of the paper is organized as follows: first it reviews the relevant literature and provides justifications for the hypotheses tested; this is followed by a methodological section in which information about the research context and details about the data gathering process and analytical method used are provided. Finally, it presents the findings, a general discussion of the results, the theoretical and managerial implications stemming from the research, and concluding remarks.

\section{Unfolding the formation of brand community commitment}

\subsection{Linking integration, participation and commitment}

Being often concerned with the problem of explaining why members of brand communities engage in participative behaviors to keep the community alive, brand community studies are often implicitly or explicitly based on the main tenets of social identity theory (Lam, Ahearne, Hu, \& Schillewaert, 2010). Social identity theory is a general socio-psychological theory which postulates that individuals have a tendency to classify themselves into social categories (such as members of a brand community), and that depending on their level of felt belongingness, they may engage in purposeful behaviors aimed at ensuring the continuance of the group (see Tajfel, 1978, 1981; Tajfel \& Turner, 1985; Ashforth \& Mael, 1989). Although the literature offers several definitions and operationalizations of these individuals' sense of belongingness to a brand community, like social integration (Madupu \& Cooley, 2010), sense of community (Galehbakhtiari \& Pouryasouri, 2015), brand community identification (Kumar \& Kumar Nayak, 2018; Hook et al., 2018) or community cohesiveness (Lin, et al., 2018), the construct of brand community integration (McAlexander et al., 2002) is the most widely supported and applied in brand community studies regardless of whether 
they are online (Habibi, Laroche, \& Richard, 2014; Kim \& Lee, 2019), offline (McAlexander et al., 2003; Schouten, McAlexander, \& Koening, 2007; Rosenbaum \& Martin, 2012), or hybrid, i.e. combining both online and offline settings (Stokburger-Sauer, 2010). Brand community integration is defined as the sense of belongingness to a brand community determined by the cumulative impact of four relational layers: other members of the brand community, the brand itself, the product, and the firm that owns the brand (McAlexander $e t$ al., 2002, 2003). Each of these creates as many types of customer-centered relationships: customer-to-product, customer-to-brand, customer(s)-to-company, and customer-tocustomer(s).

Although some research distinguishes between active and passive brand community participation (Lampe et al., 2010; Royo-Vela \& Casamassima, 2011; Sun et al., 2014), and even frames brand community participation as an attitudinal construct (Bagozzi \& Dholakia, 2006; Dessart, 2017), participation is first and foremost a behavioral construct (Brodie, Ilic, Juric, \& Hollebeek, 2013). Therefore, brand community participation can be defined as the extent to which a member actively engages in community activities and interacts with other brand community members (Tsai, Huang, \& Chiu, 2012). Due to the multiplicity of forms that participation in a social group such as a brand community can assume, it is not surprising that when brand community participation is implied in empirical studies, this concept is defined and operationalized in many different ways. These include the intentional or actual level of engagement with the brand community (Bagozzi \& Dholakia, 2006; Sánchez-Franco, Buitrago-Esquinas, \& Yñiguez, 2012; Hwang, Han, \& Hyun, 2018; Carlson, Wyllie, Rahman, \& Voola, 2019); the participation in a community's traditions, rituals and activities (Madupu \& Cooley, 2010; Hedlund, 2014; Hwang et al., 2018); the frequency with which members take part in community life (Pai \& Tsai, 2011) and the time spent within it (Carlson et al., 2019); the willingness to respond to calls (Sánchez-Franco et al., 2012), to exchange 
information (Yeh \& Choi, 2011; Chang, Hsieh, \& Lin, 2013; Pasternak et al., 2017) and to help others (Casaló et al., 2007; Yeh \& Choi, 2011; Pai \& Tsai, 2011; Chang et al., 2013; Carlson et al., 2019); the active role in value co-creation activities (Nambisan \& Baron, 2009; Liao et al., 2017) or - more generally - the willingness of community members to engage in pro-brand community citizenship behaviors (Wong, Yacine Haddoud, Kwok, \& He, 2018). Research has also suggested that the complexity of the interactions that take place in the community (Black \& Veloutsou, 2017) creates the conditions for members to play different roles corresponding to different levels of active contribution to the brand community's life (Kozinets, 1999; Lampe et al., 2010; Azar, Machado, Vacas de-Carvalho, \& Mendes, 2016; Dessart, Veloutsou, \& Morgan-Thomas, 2016; Özbölük \& Dursun, 2017, Veloutsou \& Black, 2019).

However, little is known about the effects of individuals' sense of integration in the brand community on their active behavioral participation, although there are anecdotal claims linking high (low) brand community integration with high (low) brand community participation. The causal link between brand community integration and brand community participation cannot be taken for granted: previous studies have found evidence that individuals may feel a sense of belonging to a group but this does not necessarily lead to a proportionate level of active behavioral participation (Dessart, Veloutsou, \& MorganThomas, 2015; 2016). As Wong et al. (2018) have highlighted, although active participation is of paramount importance in assessing the effectiveness of a brand community, only a very small number of studies have empirically verified models considering the direct connection among the formation, determinants and outcomes of brand community participation. Therefore, the first hypothesis is this:

H1: Brand community integration is directly and positively related to brand community participation. 
Although some scholars equate 'participation' with 'commitment' and use them as synonyms, the two constructs are conceptually different (e.g., Hook et al., 2018). 'Brand community commitment' refers to a community member's desire to sustain relationships formed within the brand community (Zhou et al. 2012). 'Participation', instead, can be considered the means through which this desire is materially fulfilled (Munnukka, Karjaluoto \& Tikkanen, 2015; Zhou et al. 2012).

The literature generally distinguishes two forms of commitment: attitudinal and behavioral. The former relates to the sense of attachment or loyalty nurtured by an individual toward a target, e.g., a brand community. The latter entails actions performed by individuals to maintain a (valued) relationship across time (Moorman, Zaltman, \& Deshpande, 1992; Jang et al., 2008). Therefore, behavioral brand community commitment is similar to participation because both involve actions and practices, while attitudinal commitment is conceptually similar to other constructs like brand community attachment (Sierra, Badrinarayanana, \& Taute, 2016). Brand community participation is about the current behavior of individuals, while brand community commitment entails a sense of loyalty to or affection for the community (Kim, Choi, Qualls, \& Han, 2008; Jang et al., 2008; Kuo \& Feng, 2013; Munnukka et al., 2015; Sierra et al., 2016) and the other brand community members (Kim et al., 2008). Commitment implies a sense of loss if the community ceased to exist (Zhou et al., 2012; Kuo \& Feng, 2013; Sierra et al., 2016; Lim \& Kumar 2017), a sense of protection of the community (Royo-Vela \& Casamassima, 2011; Sierra et al., 2016), a desire to stay in the community and to maintain relationships with others, or a more generic sense of remaining loyal to the community (Lim \& Kumar, 2017) through participation continuance (Kim, Lee, \& Hiemstra, 2004; Kim et al., 2008; Lampe et al., 2010; Hur, Ahn, \& Kim, 2011; Zhou et al. 2012; Kuo \& Feng, 2013; Munnukka et al., 2015; Liao et al., 2017). 
The approach to brand community participation and brand community commitment adopted in this research study is in line with the view of Hook et al. (2018), who suggest that brand community participation and brand community commitment are distinct indicators of participation and of community continuation, but the study contradicts the argument of these authors that they can be seen as conceptually identical. A member of the community can, in fact, participate at one point in time, but not necessarily be willing to participate further in the future. Therefore, it is hypothesized that:

H2: Brand community participation is directly and positively related to brand community commitment.

\subsection{Distinguishing between consumer-run and marketer-managed brand communities}

Brand communities can be initiated, developed, coordinated and managed both by passionate consumers of the brand that want to join together, or by marketers who are looking to develop relationships with followers (Dholakia \& Vianello, 2011). A thorough analysis of empirical research to date concerned with the constructs of brand community integration, and/or brand community participation, and/or brand community commitment (Table 1) shows that the majority of studies are focused on brand communities that are initiated and managed by marketers.

TABLE 1 ABOUT HERE

Research on the distinct types of brand communities evidences that members are often active contributors in both consumer-run and company-managed brand communities, and that both co-create value for the brand (Cova et al., 2015; Skålén et al., 2015; Black \& Veloutsou, 2017). The limited research that has to date examined differences between these two types of 
communities yields little understanding of whether they actually work differently. Sung et al. (2010) suggest that in both cases members join the community because they like the brand, while Porter, Devaraj and Sun (2013) affirm that community members create value for the brand regardless of whether the community is consumer-run or company-managed. Research has found that both types of brand communities generate similar levels of satisfaction, commitment and willingness to support (Sung et al., 2010) or to revisit the community (Jung et al., 2014). Nevertheless, it has been suggested that the two types of communities are dissimilar in terms of targeted members, purpose, and scope of activities and expression of freedom (Dholakia \& Vianello, 2011), level and form of engagement that they are capable of generating (Lee et al., 2011; Jang et al., 2008; Lee et al., 2012), and felt community trustworthiness (Jung et al., 2014). Members of the different types of brand communities may have different motives for joining and engaging in these communities. People may join a company-managed community because they are driven by instrumental purposes, e.g., they want to have access to privileged information about the product or the brand, or they may decide to join a consumer-run community because of the socialization occasions that it offers (Sung et al., 2010; Dholakia \& Vianello, 2011; Jang et al., 2008).

Very little is known about brand community integration, brand community participation and brand community commitment formation processes in the different types of communities, and in particular consumer-run and company-managed communities. Despite the literature on the topic being scant and nascent, there is enough information to suggest that consumer-run and company-managed brand communities are different. The relevant hypotheses are:

H3. Brand community (H3a) integration, (H3b) participation and (H3c) commitment are significantly higher for consumer-run than for company-managed brand communities. 
H4. The relationship between brand community integration and brand community participation is stronger for consumer-run than for marketer-managed brand communities.

H5. The relationship between brand community participation and brand community commitment is stronger for consumer-run than for marketer-managed brand communities.

Finally, since perceptions and feelings about the brand community and behaviors enacted within it may differ according to individual characteristics (e.g., Nadeem, Andreini, Salo, \& Laukkanen, 2015; Algesheimer, Borle, Dholakia, \& Singh, 2010), the hypotheses put forward were tested by taking three control variables into account: age, gender, and nationality. The overall model specified and tested in the research is represented in Figure 1.

\section{FIGURE 1 ABOUT HERE}

\section{Methodology}

Data were collected with the help and endorsement of Moto Guzzi, a leading Italian motorcycle manufacturer and one of the oldest European motorcycle producers still in operation. Research on brand communities is often focused on products and brands characterized by the high involvement of customers (Hook et al., 2018) such as cars (McAlexander et al., 2002; Algesheimer et al., 2005; Yeh \& Choi, 2011; Tsai et al., 2012; Zhou et al., 2012) and motorcycles (Schembri, 2009; Felix, 2012; Marzocchi, Morandin, \& Bergami, 2013). These product categories are characterized by high emotional involvement and intense experience for the user, making them eligible for the creation of brand communities (Tsai et al., 2012; Schembri, 2009). 
Founded in 1921 and recognized worldwide as one of the most important Italian brands in motorcycle production, Moto Guzzi can boast the presence of two brand communities (Table 2): Moto Guzzi World Club (MGWC hereafter) and (The Clan) (see Appendix 1 for additional details on both brand communities).

\section{TABLE 2 ABOUT HERE}

To collect the data, a questionnaire was administered through the official monthly newsletter of each of the two brand communities. The constructs and measurement items used in this study were drawn from previous research with minor modifications (Appendix 2). Those modifications concerned the translation from English to Italian when the questionnaire was addressed to Italian respondents. In line with the procedure suggested by Chapman and Carter (1979) the survey instrument was first rendered into Italian; then the resulting version was back translated into English by experienced bilingual researchers. An English native speaker researcher compared the two versions of the questionnaire to ensure consistency (Brislin, 1980). The measures translated were then further refined in order to be sure that terms used actually captured the underlying meaning of the construct to be measured. For respondents of other nationalities instead, the questionnaire was administered in English by using the same items employed in previous research.

Observed variables to measure the underlying latent construct of 'brand community integration' were drawn from McAlexander et al. (2002) and adapted to fit with the research context. All variables composing the first-order factors loading onto the second-order construct of integration developed and tested by McAlexander et al. (2002) were included except for items two and three of the original measurement scale referring to the customer-tobrand dimension that were not disclosed in the article. Observed variables to measure the 
latent construct of 'brand community participation' were drawn from the four-item scale of Casaló et al. (2007), reworded and adapted to fit with the research context, which comprised brand communities with both online and offline interactions. For this reason, an item from the original scale that expressly referred to the frequency with which individuals post comments and responses on online platforms was deleted. Finally, items measuring 'brand community commitment' were drawn from Mathwick et al. (2008).

For all of the observed variables included in the questionnaire, the respondents were asked to express their agreement with each statement by using a five-point Likert-type scale from fully disagree (1) to fully agree (5).

Control variables were measured as: age (in years), gender ( $1=$ female, $2=$ male $)$ and nationality (1=Italian, $2=$ non-Italian). The full version of the questionnaire was administered to members of both communities investigated (MGWC and The Clan).

A total of 2,370 questionnaires were collected. After eliminating responses from members of the company-managed brand community (The Clan) who, despite being members, did not own a motorbike, and deleting non-complete responses, 2,167 questionnaires were retained; of these 1,636 were from members of 'The Clan' community and the remaining 531 were from members belonging to MGWC. The sample of respondents $(n=2,167)$ is synthetically represented in Table 3.

TABLE 3 ABOUT HERE

A structural equation model was developed using the maximum likelihood procedure. The procedure started by estimating the measurement model and assessed the reliability and validity of the multi-item constructs using a prior exploratory (EFA) and subsequent confirmatory factor analysis (CFA) for each of the contributing constructs (Fornell \& 
Larcker, 1981; Anderson \& Gerbing, 1988). The test of the measurement model was followed by a test of the structural model of the whole dataset, considering data obtained from the two brand communities as a single dataset, and by the analysis of the overall model fit and the path coefficients for the hypothesized relationships. After assessing the validity of the baseline model, a multi-group structural equation modelling (SEM) (Steenkamp \& Baumgartner, 1998) was then used to test for invariance between the two communities. To identify differences between the consumer-run community (MGWC) and the companymanaged one (The Clan), the procedure followed the guidelines of Byrne (1998) and compared a set of increasingly restrained nested models to verify invariance of the measurement items, factorial structure of the model's theoretical constructs, hypothesized causal relations, and latent means of the constructs composing the model.

\section{Results}

\subsection{Measurement model}

The measurement model was tested with AMOS 22.0 and included all of the items composing each of the three constructs investigated: 'brand community integration' and its four underlying factors, namely customer-to-product, customer-to-brand, customer-tocompany, and customer-to-customer(s), ‘brand community participation', and 'brand community commitment'. The complete measurement model resulted in an unsatisfactory statistical fit $(\chi 2=2459.240 ; p>.000 ; \mathrm{df}=202 ; \mathrm{RMSEA}=.082 ; \mathrm{GFI}=.890 ; \mathrm{NNFI}=.887$; CFI=.898) (Tabachnick \& Fidell, 2007). To achieve a better statistical fit of the measurement model, use was made of a CFA $\chi 2$ difference test method where the correlation between constructs was constrained to one and the $\chi^{2}$ value of the constrained model was compared to that of the unconstrained model (Bagozzi, Yi, \& Phillips, 1991). This test led to identification of serious problems of correlation between two of the first-order-factors (customer-to-brand 
and customer-to-company) of the second order construct of brand community integration, with the consequence that the customer-to-company dimension was discarded. The multidimensional nature of the brand community integration construct generally stands. However, in certain settings the dimensions of the scale are adapted to fit the context. Stokburger-Sauer (2010), in assessing the importance of offline and online marketing activities in fostering customers' feelings of brand community integration in the context of diabetes patients using a specific branded blood sugar meter, did not satisfy the condition of discriminant validity for the four-factor construct of brand community integration and deleted the 'customer-to-product' dimension. Other scholars have introduced a further dimension of brand community integration, such as the relationship with the staff (Shim, Kang, Kim \& Hyun, 2017), to fit with the peculiar nature of their research context. The customer-tocompany dimension has also been deleted in other studies (see Millán \& Diaz, 2014; Shim et $a l ., 2017)$ and justified by a factual inability of the respondents to discriminate between the company and the brand. Similarly, in the context investigated here, discriminant validity between the customer-to-brand and customer-to-company was not achieved because respondents did not discriminate between Moto Guzzi as a brand and as a company. Besides deleting this factor, offending items contributing to poor fit of the measurement model were also discarded by considering the largest negative and largest positive standardized residuals as well as the scores of items' multiple squared correlations (Byrne, 1998). This procedure led to the discarding of two additional items: one from the customerto-product factor and one from the customer-to-customer(s) factor. The revised measurement model met guidelines for acceptable fit (Tabachnick \& Fidell, 2007): $\left(\chi^{2}=935.401 ; \mathrm{df}=98\right.$; RMSEA=.063; CFI=.956; NNFI=.946). Each measurement scale was assessed as reliable: Cronbach's alphas ranged from a minimum of .83 to a maximum of .92 , which is higher than the .70 threshold suggested by Nunnally (1978). In addition, the composite reliability (CR) 
and average variance extracted (AVE) of each of the constructs were above the recommended thresholds of .6 and .5, respectively (Fornell \& Larcker, 1981; Bagozzi \& Yi, 1988) (Table 4). The model also met requirements for convergent validity, with each item loading significantly and substantially (above .5) on the expected latent construct (Table 5). Finally, to reduce the risks of common method bias (Conway \& Lance, 2010), the Harman's single-factor test (Podsakoff et al., 2003) was used to compare the confirmatory factor analyses (CFAs) for the measurement model with the one-factor model. The fit indices of the one-factor model $\left(\chi^{2}=8111.42 ; \mathrm{df}=104 ; \mathrm{p}<.00 ; \mathrm{CFI}=.57 ; \mathrm{RMSEA}=.05 ; \mathrm{NNFI}=.50 ; \Delta \chi^{2}=7176.02 ;\right.$ $\Delta \mathrm{df}=6 ; \mathrm{p}<0.000)$ were significantly worse than the measurement model tested $(\mathrm{p}<001)$, giving support for this latter and confirming that problems of common method bias are unlikely.

TABLE 4 ABOUT HERE

TABLE 5 ABOUT HERE

\subsection{Structural model}

The structural model revealed a good level of fit $(\chi 2=1103.786 ; \mathrm{df}=137 ; \mathrm{p}<.000$; RMSEA=.057; GFI=.947; AGFI=.926; NFI=.944; NNFI=.938; CFI=.951). To test the reliability of the model, the squared multiple correlations for the structural equations were checked. The results showed that the model explained $60 \%$ of the variance in 'brand community commitment' and $36 \%$ of the variance in 'brand community participation'. The 
structural model supported both the two baseline hypotheses formulated: 'brand community participation' was positively and significantly explained by 'brand community integration' $(\gamma=.52 ; \mathrm{p}<.001)$ (H1 supported) and 'brand community commitment' was positively and significantly explained by 'brand community participation' ( $\gamma=.22 ; \mathrm{p}<.001)$ (H2 supported). The three control variables, age, gender and nationality, were found to differently affect the three constructs composing the model. None significantly affected 'brand community integration'. All of them affected 'brand community participation': in particular, age $(\gamma=.07$; $\mathrm{p}<.00)$, gender $(\gamma=.08 ; \mathrm{p}<.00)$ and nationality $(\gamma=-.08 ; \mathrm{p}<.00)$. Only two affected 'brand community commitment': age $(\gamma=.05 ; \mathrm{p}<.00)$ and nationality $(\gamma=-.19 ; \mathrm{p}<.00)$.

\subsection{Comparing consumer-run and company-managed brand communities}

Multi-group SEM was used to test for differences between the consumer-run (MGWC) and company-managed (The Clan) brand communities.

Before testing for mean differences across the two brand communities investigated, it was first necessary to establish that the constructs had the same meaning for members of both groups. Two tests were conducted: a test of configural invariance, i.e. that the same items loaded on the same factors in both groups, and test of metric invariance, i.e. that factor weights did not differ significantly between groups. Configural invariance was tested via estimation of the measurement model independently for both groups. All items loaded as proposed, with satisfactory fit for both the consumer-run brand (MGWC $-\chi 2=261.696$; $\mathrm{df}=98 ; \chi 2 / \mathrm{df}=2.67 ; \mathrm{RMSEA}=.056 ; \mathrm{CFI}=.966 ; \mathrm{NNFI}=.959)$ and the company-managed brand community (The Clan $-\chi 2=784 ; \mathrm{df}=98 ; \chi 2 / \mathrm{df}=8 ; \mathrm{RMSEA}=.065 ; \mathrm{CFI}=.951 ; \mathrm{NNFI}=.940)$. Although RMSEA was below the recommended threshold, the procedure is very sensitive to sample size and can appear high in otherwise satisfactory models for small samples (Bentler \& Yuan, 1999). The metric invariance test confirmed that both groups interpreted the latent 
constructs in the same way $\left(\Delta \chi^{2}=23.019 ; \Delta \mathrm{df}=16, \mathrm{p}=.113 ;\right.$ model $\chi^{2}=1068.726 ; \mathrm{df}=212$; RMSEA=.043; CFI=.95; NNFI=.949).

Once metric invariance had been demonstrated, tests of scalar invariance were used to compare mean scores (construct intercepts) on the factorial structure of the construct of 'brand community integration', 'brand community participation' and 'brand community commitment' constructs. The results reported a good fit $(\chi 2=1068.726 ; \mathrm{df}=212$;

RMSEA=.043; $\mathrm{CFI}=.955 ; \mathrm{NNFI}=.949)$, and also in this case the univariate $\chi 2$ incremental value from the base line model reveals that the probability value is higher than 0.05 . As shown in Table 6, H3a, H3b and $\mathrm{H} 3 \mathrm{c}$ are all supported. Members of the consumer-run brand community are more positive than members of the company-managed brand community about their felt level of 'brand community integration' (mean difference, $\mathrm{D}=.34$, $\mathrm{t}=2.03, \mathrm{p}<0.05)$, 'brand community participation' $(\mathrm{D}=.18, \mathrm{t}=6.52, \mathrm{p}<.001)$ and 'brand community commitment' $(\mathrm{D}=.25, \mathrm{t}=7.59, \mathrm{p}<.001)$. In addition to finding differences in the latent mean of construct, the results also found statistically significant differences of loading of each of the three dimensions loading onto the construct of 'brand community integration', and specifically customer-to-product, customer-to-brand, and customer-to-customer(s). The dimension customer-to-customer(s) was significantly more important for members of the consumer-run community than for those in the company-managed one $(D=.11, t=3.37, p<.05)$ (Table 6).

\section{TABLE 6 ABOUT HERE}

Finally, a test of structural invariance was conducted to verify if a structural model specified in one sample (e.g., the company-managed brand community, The Clan), replicates over a second independent sample from the same population (e.g., the consumer-run brand 
community, MGWC). Specifically, structural invariance is aimed at testing the two remaining hypotheses: (i) that the relationship between 'brand community integration' and 'brand community participation' is stronger for the consumer-run than for the company-managed brand community (H4), and (ii) that the relationship between 'brand community participation' and 'brand community commitment' is stronger for the consumer-run than for the company-managed brand community (H5). The results of this further restrained model were satisfactory for both groups, MGWC $(\chi 2=309.658 ; \mathrm{df}=137$; RMSEA=.049; GFI=.943; $\mathrm{AGFI}=.921 ; \mathrm{NFI}=.940 ; \mathrm{NNFI}=.957 ; \mathrm{CFI}=.965)$ and The $\mathrm{Clan}(\chi 2=964.59 ; \mathrm{df}=137 ;$ RMSEA=.061; GFI=.938; AGFI=.915; NFI=.935; NNFI=.930; CFI=.946) but did not reveal any statistically significant difference between the two communities (Table 7). H4 and H5 were thus rejected. Finally, differences between the two communities in regard to the role of the three control variables (age, gender, and nationality) were also tested. The results showed a null effect of age, gender, and nationality on 'brand community integration'. All of the control variables affected 'brand community participation': age $\left(\gamma_{\text {MGWC }}=.07 ; p<.05 ; \gamma_{\text {The Clan }}\right.$ $=.06 ; \mathrm{p}<.05)$, gender $\left(\gamma_{\text {MGWC }}=.06 ; \mathrm{p}<.00 ; \gamma_{\text {The Clan }}=.08 ; \mathrm{p}<.00\right)$ and nationality $\left(\gamma_{\text {MGWC }}=-\right.$ $.09 ; \mathrm{p}<.05 ; \gamma$ The Clan $=-.06 ; \mathrm{p}<.05)$. 'Brand community commitment', instead, was affected by age $\left(\gamma_{\text {MGWC }}=.03 ; \mathrm{p}<.05 ; \gamma_{\text {The Clan }}=.06 ; \mathrm{p}<.05\right)$ and nationality $\left(\gamma_{\text {MGWC }}=-.16 ; \mathrm{p}<.05 ; \gamma_{\text {The Clan }}\right.$ $=-.20 ; \mathrm{p}<.05)$ while the effect of gender was null.

TABLE 7 ABOUT HERE

\subsection{Mediation effects}

To test for indirect effects, the MacKinnon's (2008) procedure was preferred to the Sobel test (Sobel, 1982) because the latter assumes a symmetric distribution of the indirect effect and would, therefore, lead to biased results. MacKinnon's procedure consists of computing the 
95\% asymmetric confidence interval for each specific indirect effect by using PRODCLIN software (MacKinnon, Fritz, Williams, \& Lockwood, 2007). Table 8 reports the direct, indirect, and total effects of 'brand community integration' on 'brand community commitment' via 'brand community participation'. The results of the test confirm that 'brand community participation' mediates the relationship between 'brand community integration' and 'brand community commitment' for both the communities.

\section{TABLE 8 ABOUT HERE}

\section{Discussion and implications}

\subsection{General discussion}

The study has been designed to determine whether the process that links together brand community integration, participation and commitment are different according to whether the brand community is initiated and managed by consumers or by marketers on behalf of the brand, and on whether the four relational layers that create brand communities' members feeling of brand community integration, i.e. customer-to-product, customer-to-brand, customer-to-company, and customer-to-customer(s) (McAlexander et al., 2002, 2003) work equally across these different types of brand communities. Providing answers to these research questions involved the identification of a brand that could count on the presence of at least two brand communities that, despite being formed around the same brand, were different in terms of who initiated and managed them. Moto Guzzi and its two main brand communities were selected: MGWC, the consumer-run community, and The Clan, the company-managed community. Besides being a valuable research setting due to the presence of these communities, the Moto Guzzi case is also valuable because its two brand 
communities equally gather together people that are united by the same interest and passion for a brand. At the same time, both communities equally combine a presence in the online world via forums and social media, and a presence in the 'real world' via face-to-face meetings, in-brand fests, motorcyclist gatherings and other social events. Based on the development of the conceptual model, the analysis of the measurement model, the results of the structural model, and the results of the multi-group analysis, this study sheds light on the mechanisms that lead consumers to join, remain with, and commit themselves to the brand community depending on whether this latter is consumer-run or company-managed.

The first finding to be discussed concerns the measurement scale used in the survey to assess brand community members' felt brand community integration. The empirical test of the data collected did not provide statistical support for the four-factors structure of the second order construct of brand community integration. The test of discriminant validity revealed excessive correlation scores with customer-to-brand and led to the removal of the customerto-company dimension. The exclusion of a dimension that makes up the construct of brand community integration, however, should not lead to contestation of either the validity of the scale or the reliability of the structural relations investigated in this research. In fact, the fourfactors structure of the brand community integration construct has also not been supported by other studies (e.g. Stokburger-Sauer, 2010; Millán \& Diaz, 2014; Shim et al., 2017), suggesting that the validity of this measurement scale is dependent upon the specific features of the context investigated. For example, the very fact that the corporate brand and the company are identified under the same brand (as in the case here presented), may induce respondents not to clearly discriminate between the company and the brand, giving rise to problems of scale validity. Problems of validity are likely to happen also in cases in which the brand community is formed around a widely known product brand that may prompt respondents not to properly understand the difference between the product and the corporate 
brand (e.g., iPhone and Apple). However, since this research is an additional entry in the series of papers that have not given support to the four-factors structure of the brand community integration construct, scholars should start to question the ability of this latent variable to possess the sufficient level of abstraction that has to be granted for its application regardless of context-specific issues. Perhaps, the acknowledgment that some of the items composing the measure of the customer-to-company dimension are not disclosed by its proponents may explain the difficulty that scholars face when applying the scale in research. Setting aside problems of discriminant validity of the constructs' dimension, the results of the measurement model highlight that it is especially the customer-to-customer(s) dimension that prompts the formation of brand community integration. Whatever the form that a community may assume, whatever the product, or whatever the mechanisms regulating social life within a brand community, it is especially the relationship with others that explains why consumers develop the sense of we-ness that characterizes brand communities. This is not to say that other motives prompting integration, such as the brand and the product, are less important. They, too, contribute to integration, but do so with a lower intensity.

In addition to providing a further test of the brand community integration construct, and evaluating the explanatory power of its components, the second purpose of this study has concerned empirical confirmation (so far unexplored) of the existence of positive and significant relationships linking together brand community integration, participation, and commitment. These effects arise because when people feel that they are part of the brand community, their sense of inclusion in the social grouping prompts them to be active members and participate; and such participation is a precursor of their desire to secure the community's existence and operation in the long run. To be noted is that the research reported in this paper distinguished between 'participation' and 'commitment' (that are in some cases treated as synonymous, see e.g. Hook et al., 2018) as it included participation as a 
behavioral construct conceptually overlapping with behavioral commitment, and operationalized commitment as an attitudinal construct, avoiding any item that could have led to confounding (conceptually and statistically) the two constructs.

Interesting results are also found regarding the role played by the three control variables included in the model (age, gender, and nationality). The significant effect exerted by gender on participation is explained by the evidence that riding a motorbike and taking part in a community whose members are passionate about it are both activities that are mostly practiced by males and only seldom (or at least less frequently) by females. However, the fact that gender affects brand community participation does not prevent members from feeling committed to the community's existence in the long run, since the results revealed that brand community commitment is not significantly affected by gender.

Regarding age, the results show that older members tend to participate to a greater extent and are more committed to the communities compared to younger ones, given that Moto Guzzi is a brand that is liked and chosen especially by middle-aged consumers (the average age of the sample was 51 for 'The Clan' and 52 for 'MGWC'). Nationality, instead, was found to significantly affect brand community participation and commitment. In particular, Italians were found to be comparatively more participative and more committed to the community than people from other countries. This can be explained by the fact that the large majority of activities and social events arranged by The Clan and by MGWC take place in Italy and this can motivate the different level of participation and commitment felt by Italian and nonItalian respondents. Brand community integration, instead, was found to be independent of age, gender, and nationality, indicating that the sense of belongingness to a brand community can be formed independently of respondents' demographic variables.

Lastly, interesting findings concern invariance of measures, structural relations and underlying means of latent variables across the two brand communities investigated: the 
consumer-run (MGWC) and company-managed community (The Clan). The results of the multi-group analysis led to support of the hypotheses that brand community integration, participation and commitment are significantly higher for the consumer-run than for the company-managed brand community.

In details, the results suggest that members of the consumer-run brand community (MGWC) feel higher brand community integration, and feature higher brand community participation and commitment compared to members of the company-managed brand community (The Clan). The slightly higher level of brand community integration displayed for MGWC compared to The Clan can be partly explained by the stronger statistical effect exerted by the customer-to-customer(s) dimension. However, the statistical test of mean invariance of the latent variable of brand community integration was supported at a $95 \%$ interval confidence. More significant differences were instead found for the latent means of the other two constructs included in the model, namely brand community participation and brand community commitment.

Regarding the test of invariance of the path estimates, the results of the multi-group analysis did not reveal statistically significant differences between the consumer-run and the marketer-managed brand community. Both the hypothesis that the relationship between brand community integration and brand community participation is stronger for consumer-run than for marketer-managed brand communities $(\mathrm{H} 4)$, and the hypothesis that the relationship between brand community participation and brand community commitment is stronger for consumer-run than for marketer-managed brand communities (H5), were rejected. The rejection of these hypotheses suggests that, contrary to expectations, the chain of effects linking brand community integration, participation, and commitment works equally across the groups regardless of whether the community is consumer-run or company-managed. The lack of support for the hypothesized differences between the two communities can therefore 
be somehow considered a proxy for the general validity of the structural relationships that constitute the basis of the model tested. Whatever the ownership or the management of the community, when a certain level of integration exists, integration leads members to take part to the community and commit themselves to its continuance over time. According to this study's findings, different brand communities that form around the same brand are equal in their functioning but different in the intensity with which feelings of brand community integration, participation and commitment are felt by their members.

Multi-group invariance was also found for the three control variables (age, gender, and nationality) included in the model. The results reveal that - symmetrically with the findings for the overall model tested - age, gender, and nationality do not affect brand community integration in the consumer-run, or in the company-managed community; that all of them significantly affect brand community participation in both the consumer-run and companymanaged community; that only age and nationality affect brand community commitment in both the consumer-run and company-managed community.

\subsection{Theoretical implications}

This study sheds light on the process whereby participation and commitment in brand communities are formed holistically in environments that allow multi-channels and intense interactions among brand community members. Specifically, this study aids understanding of how the effectiveness of brand communities (also) depends on whether they are created and managed by consumers or by companies. Consumer-run and company-managed communities develop different experiences for their members: the lived experience of members joining communities created and run by consumers is significantly more intense than that felt by members belonging to company-generated and owned communities. This study is thus aligned with previous works claiming that research on brand communities needs to be more 
aware of the differences that exist within and between brand communities that may form around the same brand (e.g., Chalmers, Price, \& Schau, 2012; Arvidsson \& Caliandro, 2015; Liao, Yang, Wei, \& Guo, 2019). Communities and community experiences are not homogeneous, and depend on many different variables that affect the reasons why consumers decide to join them, their voluntary participation in the activities that are proposed by the community's managers and by its members, and their desire to maintain their presence in the community in the future.

Brand communities have for long been approached as social groups that retain a high level of similarity of their members and a predictable mechanism of functioning, due to the presence of a unifying common passion for the brand. Because of this implicit assumption of similarity of brand communities' members or - more in general - of brand community structures, scholars are now disputing the very existence of brand communities and introducing novel conceptualizations of such social aggregates (see Arvidsson \& Caliandro, 2015) due to the observed change in the behavior of community members, who are now less interactive, less keen to participate and endorse roles, and less identified around a collective identity than in the past. While this conceptual and terminological switch is fascinating and beneficial for revamping scholarly debate on brand communities, brand communities (in their oldest sense, see Muñiz and O'Guinn, 2001) exist and are alive. What is currently lacking is a theoretical and empirical advance in knowledge about what a current, up-to-date brand community is and how a current, up-to-date brand community works. Thanks to technological advances that allow an easier gathering of consumers within a shared virtual environment (e.g., branded Facebook pages) brand community research has now trivialized its focus on consumers' aggregates that, despite grouping together consumers with a common passion or interest for a brand, feature lower connections among their members and less recurrent collective social practices, since membership of such brand communities can be more easily gained compared 
to more traditional communities in which membership is less easily acquired. Consequently, although this study is primarily intended to contribute to the sub-stream of studies dealing with heterogeneity in brand communities, it contributes more in general to the broader field of brand community research by offering the case of a brand and its brand communities that are tightly aligned with the Muñiz and O'Guinn (2001) conceptualization. Both MGWC and The Clan can be somehow considered 'real' brand communities in which the passion for a brand is combined with the presence of structured relations among its members and with a sense of we-ness that is felt by consumers that join and stay within the community. At the same time, the communities studied here are characterized by an intricate social life in which virtual and face-to-face interactions are intertwined and jointly involved in the formation and maintenance of the community itself. Research should be increasingly sensitive to brand communities of this kind, where the different interactive channels present are seen neither as substitutes one for the other, nor as addressed to different targets of consumers. Rather, online and face-to-face interactions and encounters among brand community members are integrated and seen as a synergistic combination of social happenings that make up the community. Theoretical elaborations and subsequent empirical works should somehow overcome the 'de facto' separation between online and offline brand community studies that has been created in the past few decades, and they should shift toward a more holistic understanding of their functioning by emphasizing the existing connections and the impossibility of separating virtual and face-to-face interactions that may take place in current brand communities.

\subsection{Managerial implications}

The findings of this study have at least three managerial implications that are especially addressed to those companies that can count on the presence of both consumer-run and 
company-managed brand communities. Since the mechanisms connecting brand community integration, participation, and commitment are invariant across the two types of community, marketers and brand community managers should be aware that what makes the two types of communities different is the intensity with which each of these mechanisms manifests itself. Purposeful strategies and tactics are thus needed to capture the highest possible value from these communities by considering them as synergistic rather than rival relationship marketing tools. Designing integrative strategies and activities between the two communities - such as organizing meetings, brand fests and other collective encounters involving all of the communities formed around the brand regardless of whether they are consumer-run or company managed - will enable managers to enhance the participants' experience in both communities, leading to an overall competitive reinforcement of the brand. This is especially important in present times: the availability of and ease of access to social networks and other web-enhanced platforms are fostering the proliferation of consumer-run fan pages and discussion forums that set up their own rules of interaction, organize their own social activities, and propose their own set of community values. Marketers have scant possibilities to coordinate these scattered communities, and run the risk of passively witnessing the creation and growth of consumers' groups that, though formed by brand lovers, could promote the formation of a brand-ethos that is loosely aligned with what that company wants to promote. For example, placing the brand near to a socio-political ideology (e.g., Harley Davidson's macho-patriotism, see Schouten \& McAlexander, 1995), despite charging the brand with political meanings, could be beyond the brand strategy's scope. When this happens, the organization of collective encounters and of other social activities can be a suitable way to achieve stronger coordination and networking among brand communities, and higher convergence upon a definite set of values which are supported by all members of the brand communities (no matter whether they are consumer-run or company-managed). 
Second, the findings indicate that consumer-run brand communities are especially important for fostering interactions among peers, while company-managed brand communities may be well suited to more strongly cultivating consumers' relationships with other brand communities' relational layers, such as the product or the brand. These make different types of brand communities suited to achieving different results: ideally, consumer-run communities should be leveraged for all those brand-related activities designed to foster participation of the members and interactions among them. Company-managed communities seem, instead, to be more suited to all those branding activities that are centered on enhancing consumers' knowledge or consumers' relationships with the brand or with the product they own.

Third, marketers and brand community managers should devote greater attention to studying what induces consumers to feel integrated in brand communities. Brand communities, like other tools of relationship marketing, are, in many cases, used for commercial reasons while overlooking the collective glue that binds them and that makes them different from any other type of branding effort. Put differently, the commercial results stemming from the existence of a brand community should not be considered as the aim brand managers and brand community managers should strive to achieve; but rather, as a consequence of their ability to fulfill the goal of creating groups of passionate consumers. Focusing on integration and maintaining control over the mechanisms that regulate their formation is beneficial to securing the maintenance of communities that work without necessarily investing resources to continue their existence.

\section{Limitations and further research}

The results, theoretical contributions, and managerial implications of this study must be viewed in light of its limitations. The first limitation concerns the operationalization of the 
brand community commitment construct used. In this study, brand community commitment has been measured as a unidimensional multi-item construct. Although this is by far the most common approach (Jang et al., 2008; Kim et al., 2008; Hur et al., 2011; Zhou et al., 2012; Chen \& Ku, 2013; Kuo \& Feng, 2013; Munnukka et al., 2015; Relling, Schnittka, Sattler \& Johnen, 2016; Jinghua Huang, 2017; Lim \& Kumar, 2017), and although it is far better than other existing operationalizations of the construct, which have relied on a single item measure of brand community commitment (Woisetschlager, Hartleb \& Blut, 2008; Jung, Kim \& Kim, 2014), one can argue that the construct is composed of an affective, normative, and calculative dimension (Meyer \& Allen, 1991). Further studies could test whether participation has a differential impact on commitment if considered as a multi-dimensional multi-item construct.

Second, the data collection process ensured that all respondents were members of the specific brand communities under investigation. Data were collected from two communities of supporters of the same brand and did not consider overlaps between the two communities, consumers that have joined and have an active role in both the consumer-run and the company-managed brand community. Future research should try to collect data from more communities and test the model by distinguishing consumers that joined the consumer-run community, consumers that joined the company-managed community, and consumers that joined both types of community. Community ownership or management is the main exogenous variable that this study identifies to grasp differences between communities. However, it is only one of the myriad variables that may affect the different functioning of different brand communities.

Finally, given the nature of communication among brand community members, the exact makeup of their online and offline interactions and participation was difficult to determine. Members of both communities have the option of networking with other members both 
online and offline, and of choosing their preferred mode of interaction at their convenience. It was not possible to identify clearly the net contribution of each kind of interaction and the role that these different channels may have played in determining higher(lower) scores of brand community integration, participation and commitment and higher(lower) intercept scores of the connections among them. There is room for future studies looking at existing differences between different types of brand communities, to evaluate whether the presence of both an online and offline mode of interaction affects their functioning.

\section{Conclusion}

This study is one of the few conducted to date which have connected brand community integration, participation and commitment within a single framework and tested differences between two communities formed around the same brand but different in terms of who initiates and manages them. Starting from the assumption that consumer-run and companymanaged brand communities - although effective - have differences, it tests whether the different consumer-centric relational layers that make up brand community integration (McAlexander et al., 2002; 2003), and the average levels of brand community participation and commitment depend upon whether the community is consumer-run or companymanaged. The pressing urgency of marketers to find actionable and effective ways to prompt participation in communities, as well as the presence of a multiplicity of communities that form around the brand (online and offline), places great strains on marketers and community managers. It requires a deeper understanding of whether and how these communities are identical, synergistic or antagonist. The results reported in this study suggest that consumerrun communities generate a higher sense of inclusiveness, higher participation and higher commitment of members compared to company-managed communities. However, there is a 
need for further investigation of existing differences between the two types of community in future empirical efforts.

\section{References}

Algesheimer, R., Dholakia, U. M., \& Herrmann, A. (2005). The social influence of brand community: Evidence from European car clubs. Journal of Marketing, 69(3), 19-34.

Algesheimer, R., Borle, S., Dholakia, U. M., \& Singh, S. S. (2010). The impact of customer community participation on customer behaviors: An empirical investigation. Marketing Science, 29(4), 756-769.

Anderson, J. C., \& Gerbing, D. W. (1988). Structural equation modelling in practice: A review and recommended two-step approach. Psychological Bulletin, 193(3), 411-423.

Antorini, Y. M., Muñiz Jr, A. M., \& Askildsen, T. (2012). Collaborating with customer communities: Lessons from the LEGO Group. MIT Sloan Management Review, 53(3), 7395.

Arvidsson, A., \& Caliandro, A. (2015). Brand public. Journal of Consumer Research, 42(5), 727-748.

Ashforth, B. E., \& Mael, F. (1989). Social identity theory and the organization. Academy of Management Review, 14(1), 20-39.

Azar, S.L., Machado, J.C., Vacas de-Carvalho, L., \& Mendes, A. (2016). Motivations to interact with brands on Facebook - Towards a typology of consumer-brand interactions. Journal of Brand Management, 23(2), 153-178.

Bagozzi, R.P., \& Dholakia, U.M. (2006). Antecedents and purchase consequences of customer participation in small group brand communities. International Journal of Research in Marketing, 23(1), 45-61

Bagozzi, R. P., \& Yi, Y. (1988). On the evaluation of structural equation models. Journal of the Academy of Marketing Science, 16(1), 74-94.

Bagozzi, R. P., Yi, Y., \& Phillips, L. W. (1991). Assessing construct validity in organizational research. Administrative Science Quarterly, 36(3), 421-458.

Bentler, P. M., \& Yuan, K. H. (1999). Structural equation modeling with small samples: Test statistics. Multivariate Behavioral Research, 34(2), 181-197.

Black, I., \& Veloutsou, C. (2017). Working Consumers: Co-Creation of Brand Identity, Consumer Identity and Brand Community Identity. Journal of Business Research, 70(January), 416-429.

Bonnemaizon, A., Cova, B., \& Louyot, M-C. (2007). Relationship Marketing in 2015: A Delphi Approach. European Management Journal, 25(1), 50-59.

Brislin, R. W. (1980). Translation and content analysis of oral and written materials. In H. C. Triandis and J. W. Berry (Eds.). Handbook of cross-cultural psychology (pp. 389-444). Boston, MA: Allyn and Bacon.

Brodie, R. J., Ilic, A., Juric, B., \& Hollebeek, L. (2013). Consumer engagement in a virtual brand community: An exploratory analysis. Journal of Business Research, 66(1), 105-114. 
Byrne, B. M. (1998). Structural equation modeling with LISREL, PRELIS and SIMPLIS: Basic concepts, applications and programming. Psychology Press: Taylor \& Francis.

Carlson, J., Wyllie, J., Rahman, M., \& Voola, R. (2019). Enhancing brand relationship performance through customer participation and value creation in social media brand communities. Journal of Retailing and Consumer Services, 50, 333-341.

Casaló, L., Flavián, C., \& Guinalíu, M. (2007). The impact of participation in virtual brand communities on consumer trust and loyalty: The case of free software. Online Information Review, 31(6), 775-792.

Chalmers, T., Price, L. L., \& Schau, H. J. (2012). When differences unite: Resource dependence in heterogeneous consumption communities. Journal of Consumer Research, 39(5), 1010-1033.

Chang, A., Hsieh, S., \& Lin, F. (2013). Personality Traits That Lead Members of Online Brand Communities to Participate in Information Sending and Receiving. International Journal of Electronic Commerce, 17(3), 37-61.

Chapman, D. W., \& Carter, J. F. (1979). Translation procedures for the cross cultural use of measurement instruments. Educational Evaluation and Policy Analysis, 1(3), 71-76.

Chen, C.D., \& Ku, E. (2013). Bridging indistinct relationships and online loyalty: evidence from online interest based communities. Online Information Review, 37(5), 731-751.

Chou, C.M. (2014). Social Media Characteristics, Customer Relationship and Brand Equity. Journal of Applied Business and Economics, 16(1), 128-139.

Clark, M., Black, H. G., \& Judson, K. (2017). Brand community integration and satisfaction with social media sites: a comparative study. Journal of Research in Interactive Marketing, 11(1), 39-55.

Coelho, P. S., Rita, P., \& Santos, Z. R. (2018). On the relationship between consumer-brand identification, brand community, and brand loyalty. Journal of Retailing and Consumer Services, 43, 101-110.

Conway, J. M., \& Lance, C. E. (2010). What reviewers should expect from authors regarding common method bias in organizational research. Journal of Business and Psychology, 25(3), 325-334.

Cova, B., Pace, S., \& Skålén, P. (2015). Brand volunteering: Value co-creation with unpaid consumers. Marketing Theory, 15(4), 465-485.

Demiray, M. \& Burnaz, S. (2019). Exploring the impact of brand community identification on Facebook: Firm directed and self-directed drivers. Journal of Business Research, 96(March), 115-124.

Dessart, L. (2017). Social media engagement: a model of antecedents and relational outcomes. Journal of Marketing Management, 33(5-6), 375-399

Dessart, L., Veloutsou, C., \& Morgan-Thomas, A. (2015). Consumer engagement in online brand communities: a social media perspective. Journal of Product and Brand Management, 24(1), 28-42.

Dessart, L., Veloutsou, C., \& Morgan-Thomas, A. (2016). Capturing consumer engagement: duality, dimensionality and measurement. Journal of Marketing Management, 32(5/6), 399-426.

Dholakia, U., \& Vianello, S. (2011). Effective Brand Community Management: Lessons from Customer Enthusiasts. The IUP Journal of Brand Management, 8(1), 7-21. 
Felix, R. (2012). Brand Communities for Mainstream Brands: The Example of the Yamaha R1 Brand Community. Journal of Consumer Marketing, 29(3), 225-232.

Fornell, C., \& Larcker, D. (1981). Evaluating structural equation models with unobservable variables and measurement error. Journal of Marketing Research, 18(1), 39-50.

Fournier, S., \& Lee, L. (2009). Getting Brand Communities Right. Harvard Business Review, 87(4), 105-111.

Füller, J., Matzler, K., \& Hoppe, M. (2008). Brand community members as a source of innovation. Journal of Product Innovation Management, 25(6), 608-619.

Galehbakhtiari, S. (2015). A hermeneutic phenomenological study of online community participation: Applications of Fuzzy Cognitive Maps. Computers in Human Behavior, 48, 637-643.

Gruner, R. L., Homburg, C., \& Lukas, B. A. (2014). Firm-hosted online brand communities and new product success. Journal of the Academy of Marketing Science, 42(1), 29-48.

Habibi, M.R., Laroche. M. \& Richard M.-O. (2014). The roles of brand community and community engagement in building brand trust on social media. Computers in Human Behavior, 37(August), 152-161.

Hedlund, D.P. (2014). Creating value through membership and participation in sport fan consumption communities. European Sport Management Quarterly, 14(1), 50-71.

Hook, M., Baxter, S., \& Kulczynsk A. (2018). Antecedents and consequences of participation in brand communities: a literature review. Journal of Brand Management, 25(4), 277-292.

Hook, M., Baxter, S., \& Kulczynsk A. (2020). 'I'm like you, you're like me, we make a great brand community!' Similarity and children's brand community participation. Journal of Retailing and Consumer Services, 52 (January), (in press https://doi.org/10.1016/j.jretconser.2019.101895).

Hur, W-M., Ahn, K-H., \& Kim, M. (2011). Building brand loyalty through managing brand community commitment. Management Decision, 49(7), 1194-1213.

Hwang, J., Han, H., \& Hyun, S.S. (2018). The antecedents and consequences of visitors' participation in a private country club community: The moderating role of extraversion. Journal of Destination Marketing \& Management, 7(March), 89-100

Jang, H., Olfman, L., Ko, I., Koh, J., \& Kim, K. (2008). The influence of on-line brand community characteristics on community commitment and brand loyalty. International Journal of Electronic Commerce, 12(3), pp. 57-80.

Jinghua Huang, Y.J. (2017). Why do consumers participate in brand microblogs?. Electronic Commerce Research and Applications, 24(July-August), 1-11.

Johnson, D., \& Lowe, B. (2015). Emotional Support, Perceived Corporate Ownership and Skepticism Toward Out-groups in Virtual Communities. Journal of Interactive Marketing, 29(February), 1-10.

Judson, K., Devasagayam, R., \& Buff, C. 2014; Self-Perceived Brand Relevance of and Satisfaction with Social Media. The Marketing Management Journal, 22(2), 131-144.

Jung, N.A., Kim, S., \& Kim S. (2014). Influence of consumer attitude toward online brand community on revisit intention and brand trust. Journal of Retailing and Consumer Services, 21(4), 581-589. 
Kamboj, S., \& Rahman, Z. (2017). Understanding customer participation in online brand communities: Literature review and future research agenda. Qualitative Market Research: An International Journal, 20(3), 306-334.

Kim, A., Choi, J., Qualls, W., \& Han, K. (2008). It takes a marketplace community to raise brand commitment: The role of online communities. Journal of Marketing Management, 24(3/4), 409-431.

Kim, J., \& Lee, K.H. (2019). Influence of integration on interactivity in social media luxury brand communities. Journal of Business Research, 99, 422-429.

Kim, W.G., Lee, C., \& Hiemstra, S.J. (2004). Effects of an online virtual community on customer loyalty and travel product purchases. Tourism Management, 25(3), 343-355.

Kozinets R.V. (1999). E-tribalized marketing: the strategic implications of virtual communities of consumption. European Management Journal, 17(3), 252-264.

Kumar, J., \& Kumar Nayak, J. (2018). Brand community relationships transitioning into brand relationships: Mediating and moderating mechanisms. Journal of Retailing and Consumer Services, 45, 64-73.

Kumar, J. (2019). How psychological ownership stimulates participation in online brand communities? The moderating role of member type. Journal of Business Research, 105(December), 243-257.

Kumar, J., \& Kumar Nayak, J. (2019). Brand engagement without brand ownership: a case of non-brand owner community members. Journal of Product \& Brand Management, 28(2), 216-230

Kuo, Y.-F., \& L.-H. Feng. 2013. Relationships among community interaction characteristics, perceived benefits, community commitment, and oppositional brand loyalty in online brand communities. International Journal of Information Management, 33(6), 948-962.

Lam, S. K., Ahearne, M., Hu, Y., \& Schillewaert, N. (2010). Resistance to brand switching when a radically new brand is introduced: A social identity theory perspective. Journal of Marketing, 74(6), 128-146.

Lampe, C., Wash, R., Velasquez, A., \& Ozkaya, E. (2010). Motivations to participate in online communities. In Proceedings of the 28th international conference on human factors in computing systems (pp. 1927-1936). New York: ACM.

Lee, D., Kim, H., \& Kim, J. K. (2011). The impact of online brand community type on consumer's community engagement behaviors: Consumer-created vs. marketer-created online brand community in online social networking web sites. Cyberpsychology, Behavior, and Social Networking, 14(1/2), 59-63.

Lee, D., Kim, H.S., \& Kim, J.K. (2012). The role of self-construal in consumers' electronic word of mouth (eWOM) in social networking sites: A social cognitive approach. Computers in Human Behavior, 28(3) 1054-1062.

Liao, J., Huang, M., \& Xiao, B. (2017). Promoting continual member participation in firmhosted online brand communities: An organizational socialization approach. Journal of Business Research, 71(February), 92-101.

Liao, J., Yang, D., Wei, H. and Guo, Y. (2019). The bright side and dark side of group heterogeneity within online brand community. Journal of Product \& Brand Management (in press https://doi.org/10.1108/JPBM-08-2018-1972). 
Lim, H. \& Kumar A. (2017). Variations in consumers' use of brand online social networking: A uses and gratifications approach. Journal of Retailing and Consumer Services (in press, https://doi.org/10.1016/j.jretconser.2017.10.015)

Lin, C.-W., Wang, K-Y, Chang S.-H., \& Lina, J.A. (2018). Investigating the development of brand loyalty in brand communities from a positive psychology perspective. Journal of Business Research (in press, https://doi.org/10.1016/j.jbusres.2017.08.033).

MacKinnon, D. P. (2008). Introduction to statistical mediation analysis. Mahwah, NJ: Erlbaum.

MacKinnon, D. P., Fritz, M. S., Williams, J., \& Lockwood, C. M. (2007). Distribution of the product confidence limits for the indirect effect: Program PRODCLIN. Behavior Research Methods, 39(3), 384-389.

Madupu, V., \& Cooley, D. O. (2010). Antecedents and consequences of online brand community participation: A conceptual framework. Journal of Internet Commerce, 9(2), 127-147.

Malinen, S. (2015). Understanding user participation in online communities: A systematic literature review of empirical studies. Computers in Human Behavior, 46, 228-238.

Manchanda, P., Packard, G., \& Pattabhiramaiah, A. (2015). Social dollars: The economic impact of customer participation in a firm-sponsored online customer community. Marketing Science, 34(3), 367-387.

Martin, M. C., Moriuchi, E., Smith, R. M., Moeder, J. D. \& Nichols, C. (2015). The importance of university traditions and rituals in building alumni brand communities and loyalty. Academy of Marketing Studies Journal, 19(3), 107-118.

Marzocchi, G., Morandin, G., \& Bergami, M. (2013). Brand communities: loyal to the community or the brand? European Journal of Marketing, 47(1/2), 93-114.

Mathwick, C., Wiertz, C., \& De Ruyter, K. (2008). Social capital production in a virtual P3 community. Journal of Consumer Research, 34(6), 832-849.

McAlexander, J. H., Schouten, J.W., \& Koenig, H. F. (2002). Building brand community. Journal of Marketing, 66(1), 38-54.

McAlexander, J.H, Kim, S.K. \& Roberts, S.D. (2003). Loyalty: The Influences of Satisfaction and Brand Community Integration. Journal of Marketing Theory and Practice, 11(4), 1-8.

Meyer, J. P., \& Allen, N. J. (1991). A three-component conceptualization of organizational commitment. Human Resource Management Review, 1(1), 61-89.

Millán, Á., \& Díaz, E. (2014). Analysis of consumers' response to brand community integration and brand identification. Journal of Brand Management, 21(3), 254-272.

Moorman, C., Zaltman, G., \& Deshpande, R. (1992). Relationships between providers and users of market research: The dynamics of trust. Journal of Marketing Research, 29(3), 314-328.

Muñiz, A. M., \& O'Guinn, T. C. (2001). Brand community. Journal of Consumer Research, 27(4), 412-432.

Munnukka, J., Karjaluoto, H. \& A. Tikkanen. 2015. Are Facebook brand community members truly loyal to the brand? Computers in Human Behavior, 51(A), 429-439.

Nadeem, W., Andreini, D., Salo, J., \& Laukkanen, T. (2015). Engaging consumers online through websites and social media: A gender study of Italian Generation Y clothing consumers. International Journal of Information Management, 35(4), 432-442. 
Nambisan, S., \& Baron, R.A. (2009). Virtual customer environments: Testing a model of voluntary participation in value co-creation activities. Journal of Product Innovation Management, 26(4), 388-406.

Nambisan, S., \& Baron, R.A. (2010). Different roles, different strokes: organizing virtual customer environments to promote two types of customer contributions. Organization Science, 21(2), 554-572.

Nunnally, J. C. (1978). Psychometric theory (2nd ed.). New York: McGraw-Hill.

Özbölük, T., \& Dursun, Y. (2017). Online brand communities as heterogeneous gatherings: a netnographic exploration of Apple users. Journal of Product \& Brand Management, 26(4), 375-385.

Pai, P.-Y. \& Tsai, H.T. (2011). How virtual community participation influences consumer loyalty intentions in online shopping contexts: an investigation of mediating factors.

Behaviour \& Information Technology, 30(5), 603-615

Pasternak, O., Veloutsou, C., \& Morgan-Thomas, A. (2017). Self-presentation, Privacy and EWOM in Social Media. Journal of Product \& Brand Management, 26(4), 415-428.

Podsakoff, P. M., MacKenzie, S. B., Lee, J. Y., \& Podsakoff, N. P. (2003). Common method biases in behavioral research: A critical review of the literature and recommended remedies. Journal of Applied Psychology, 88(5), 879.

Porter, S.E., Devaraj, S., \& Sun D. (2013). A Test of Two Models of Value Creation in Virtual Communities. Journal of Management Information Systems, 30(1), 261-292.

Quint, M. (2013), "Run marketing as a business: the transformation of SAP Marketing" (Part I), Colombia Business School, available at:www8.gsb.columbia.edu/

Relling, M., Schnittka, O., Sattler, H., \& Johnen, M., 2016. Each can help or hurt: Negative and positive word of mouth in social network brand communities. International Journal of Research in Marketing, 33(1), 42-58.

Rosenbaum, M., \& Martin, D. (2012). Wearing community: why customers purchase a service firm's logo products. Journal of Services Marketing, 26(5), 310-321.

Royo-Vela, M., \& Casamassima, P. (2011). The influence of belonging to virtual brand communities on consumers' affective commitment, satisfaction and word-of-mouth advertising: The ZARA case. Online Information Review, 35(4), 517-542.

Sánchez-Franco, M., Buitrago-Esquinas, E., \& Yñiguez, R. (2012). How to intensify the individual's feelings of belonging to a social networking site?: Contributions from community drivers and post-adoption behaviours. Management Decision, 50(6), 11371154.

Schembri, S. (2009). Reframing brand experience: The experiential meaning of HarleyDavidson. Journal of Business Research, 62(12), 1299-1310.

Schouten, J. W., \& McAlexander, J. H. (1995). Subcultures of consumption: An ethnography of the new bikers. Journal of Consumer Research, 22(1), 43-61.

Schouten, J. W., McAlexander, J. H., \& Koening, H. F. (2007). Transcendent Customer Experience and Brand Community. Journal of the Academy of Marketing Science, 35(3), 357-368.

Shim, C., Kang, S., Kim, I., \& Hyun, S.S. (2017). Luxury-cruise travellers' brand community perception and its consequences, Current Issues in Tourism, 20(14), 1489-1509. 
Sierra, J., Badrinarayanana, V., \& Taute, H. (2016). Explaining behavior in brand communities: A sequential model of attachment, tribalism, and self-esteem. Computers in Human Behavior, 55(B), 626-632.

Skålén, P., Pace, S., \& Cova, B. (2015). Firm-brand community value co-creation as alignment of practices. European Journal of Marketing, 49(3/4), 596-620.

Sobel, M. E. (1982). Asymptotic intervals for indirect effects in structural equations models. In S. Leinhart (Ed.), Sociological methodology (pp. 290-312). San Francisco: Jossey-Bass.

Steenkamp, J. B. E., \& Baumgartner, H. (1998). Assessing measurement invariance in crossnational consumer research. Journal of Consumer Research, 25(1), 78-90.

Stokburger-Sauer, N. (2010). Brand community: drivers and outcomes. Psychology and Marketing, 27(4), 347-368.

Sun N., Pei-Luen Rau, P.P-L., \& Ma, L. (2014). Understanding lurkers in online communities: A literature review. Computers in Human Behavior, 38(September), 110-117.

Sung, Y., Kim, Y., Kwon, O., \& Moon, J. (2010). An Explorative Study of Korean Consumer Participation in Virtual Brand Communities in Social Network Sites. Journal of Global Marketing, 23(5), 430-445

Tabachnick, B. G., \& Fidell, L. S. (2007). Using multivariate statistics (5th ed.). New York: Allyn and Bacon.

Tajfel, H. (1978). The achievement of group differentiation. In H. Tajfel (Ed.). Differentiation between social groups: Studies in the social psychology of intergroup relations (pp. 77-98). London: Academic Press.

Tajfel, H. (1981). Human groups and social categories: Studies in social psychology. Cambridge: Cambridge University Press.

Tajfel, H., \& Turner, J. C. (1985). The social identity theory of intergroup behavior. In S. Worchel \& W. G. Austin (Eds.), Psychology of intergroup relations (pp. 7-24). Chicago: Nelson-Hall.

Tsai, H.-T., Huang, H.-C., \& Chiu, Y.-L. (2012). Brand community participation in Taiwan: examining the roles of individual-, group-, and relationship-level antecedents. Journal of Business Research, 65(5), 676-684.

Veloutsou, C., \& Black, I. (2019). Creating and managing participative brand communities: The roles members perform. Journal of Business Research (in press https://doi.org/10.1016/j.jbusres.2019.06.032).

Veloutsou, C., \& Guzmán, F. (2017). The evolution of brand management thinking over the last 25 years as recorded in the Journal of Product and Brand Management. Journal of Product \& Brand Management, 26(1), 2-12.

Veloutsou, C., \& Moutinho, L. (2009). Brand relationships through brand reputation and brand tribalism. Journal of Business Research, 62(3), 314-322.

Vohra, A., \& Bhardwaj, N. (2019a). Customer engagement in an e-commerce brand community: An empirical comparison of alternate models. Journal of Research in Interactive Marketing, 13(1), 2-25.

Vohra, A., \& Bhardwaj, N. (2019b). From active participation to engagement in online communities: Analysing the mediating role of trust and commitment. Journal of Marketing Communications, 25(1), 89-114. 
Warren, C. J., \& Brownlee, E. A. (2013). Brand community integration in a niche sport: A league-wide examination of online and offline involvement in minor league soccer in North America. International Journal of Sport Management and Marketing, 13(3-4), 158172 .

Woisetschläger, D.M., Hartleb, V., \& Blut, M. (2008). How to make brand communities work: Antecedents and consequences of consumer participation. Journal of Relationship Marketing, 7(3), 237-256.

Wong, T.C., Yacine Haddoud, M., Kwok, Y.K., \& He, H. (2018). Examining the key determinants towards online pro-brand and anti-brand community citizenship behaviours: A two stage approach. Industrial Management \& Data Systems, 118(4), 850-872.

Yeh, Y-H., \& Choi, S.M. (2011). MINI-lovers, maxi-mouths: An investigation of antecedents to eWOM intention among brand community members. Journal of Marketing Communication, 17(3), 145-162.

Zhou, Z., Zhang, Q., Su, C., \& Zhou, N. (2012). How do brand communities generate brand relationships? Journal of Business Research, 65(7), 890-895. 


\section{Appendix 1. Description of 'Moto Guzzi World Club' (MGWC) and 'The Clan'}

MGWC is a consumer-generated and -run brand community that gathers together about 14,000 Moto Guzzi owners with 49 local branches located primarily in Italy but also in other countries. Founded in 2002 in Noale, a small town near to Venice, the purpose of MGWC is to create and organize events, reunions, meetings, and contests and provide Moto Guzzi owners with the chance to meet each other and to develop relationships. To become a member, individuals are required to own a Moto Guzzi motorbike. Members receive a 'membership card' and have the right to participate in a motorbike championship, open only to Moto Guzzi owners, have privileged access to some brand events, a full year free subscription to a company magazine, and receive a gadget that varies from one year to another. Members interact in various settings, since the social life of MGWC takes place in offline settings through physical interactions between community members, but also counts a rather active and populated Facebook group (c.a. 16,000 members to September 2018).

The Clan, is a company-generated and managed-brand community, established in 2014 and, to date, counts approximately 14,000 members. The Clan' targets both Moto Guzzi owners and non-owners, and is one of the several projects carried out by the company to enhance the establishment of a direct relationship with consumers. The Clan is hosted in an online platform managed by the company, where members can share and obtain each other's suggestions to improve their "Moto Guzzi experience" and gain access to news and information concerning the brand, the company, its products, organized events and brand initiatives. Membership to the community allows members to gain preferential access to community-building brand activities that favor the creation of personal relationships between members, such as events and brand fests organized by the brand for the members and a free pass to take part in brand events. Membership to the Clan also provides additional benefits, such as access to premium customers' services, discounts on post-sales services and on accessory purchasing. 
Appendix 2. Measurement scales

Brand community integration (source: McAlexander et al., 2002)

- Customer-to-product

- I love my MOTO GUZZI

- I am proud of my MOTO GUZZI

- My MOTO GUZZI is one of my favorite possessions

- My MOTO GUZZI is fun to drive

- Customer-to-brand

○ I value the MOTO GUZZI heritage

- I would recommend MOTO GUZZI to my friends

○ If I were to replace my MOTO GUZZI vehicle, I would buy another MOTO GUZZI

- MOTO GUZZI is of the highest quality

- MOTO GUZZI is the ultimate motorbike

- Customer-to-company*

- The company MOTO GUZZI understands my needs

- The company MOTO GUZZI cares about my opinions

- Customer-to-customer(s)

- I have met wonderful people because of owning my MOTO GUZZI

- I feel a sense of kinship with other MOTO GUZZI owners

- I have an interest in a club for MOTO GUZZI owners

- Brand community commitment (source: Mathwick et al., 2008)

- The relationship I have with this BRAND COMMUNITY** is important to me

- I really care about the fate of this BRAND COMMUNITY**

- The relationship I have with this BRAND COMMUNITY** is one I intend to maintain indefinitely

- Brand community participation (source: Casaló et al., 2007)

- I assist fellow of the BRAND COMMUNITY** in finding solutions to their problems

- I am willing to work together with others to improve the BRAND COMMUNITY** experience

- I keep up with the latest technical developments in order to make useful contributions to the BRAND COMMUNITY**

* The customer-to-company dimension was deleted due to lack of discriminant validity.

** The questionnaire administered explicitly included the name of the communities investigated, MGWC and The Clan depending on the community to which the questionnaire was distributed.

N.B. The scale is anchored from 1 "I totally disagree" to 5 "I totally agree). 
Table 1. Previous research capturing brand community integration, participation and commitment

\begin{tabular}{|c|c|c|c|c|c|}
\hline & & & \multicolumn{3}{|c|}{ Creators of the communities } \\
\hline & & & Company & Consumers & Not specified \\
\hline \multirow{12}{*}{ 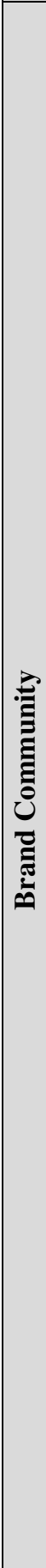 } & \multirow{4}{*}{ 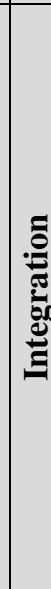 } & Online & $\begin{array}{l}\text { Chou (2014); Judson et al (2014); } \\
\text { Relling } \text { et al. (2016); Clark et al. } \\
\text { (2017); Kim \& Lee (2019) }\end{array}$ & & $\begin{array}{l}\text { Sánchez-Franco et al. (2012); } \\
\text { Habibi et al (2014) }\end{array}$ \\
\hline & & Offline & $\begin{array}{l}\text { McAlexander } \text { et al. (2003); } \\
\text { Schouten } \text { et al. }(2007) ; \\
\text { Rosenbaum \& Martin (2012); } \\
\text { Marzocchi } \text { et al. (2013); Shim et } \\
\text { al. (2017) }\end{array}$ & & \\
\hline & & $\begin{array}{c}\text { Online \& } \\
\text { Offline }\end{array}$ & $\begin{array}{l}\text { Stokburger-Sauer (2010); } \\
\text { Warren \& Brownlee (2013); } \\
\text { Millan \& Diaz (2014) }\end{array}$ & & \\
\hline & & $\begin{array}{c}\text { Not } \\
\text { specified }\end{array}$ & $\begin{array}{l}\text { McAlexander } \text { et al. (2006); } \\
\text { McAlexander \& Koenig (2010); } \\
\text { Martin } \text { et al. } \text { (2015) }\end{array}$ & & \\
\hline & \multirow{4}{*}{ | } & Online & $\begin{array}{l}\text { Woisetschlager et al. (2008); } \\
\text { Nambisan \& Byron (2009); Sung } \\
\text { et al. (2010); Pai \& Tsai (2011); } \\
\text { Yeh \& Choi (2011); Chang } \text { et al. } \\
\text { (2013); Dessart } \text { et al. (2016); } \\
\text { Dessart (2017); Carlson et al. } \\
\text { (2019), Kumar (2019) }\end{array}$ & & $\begin{array}{l}\text { Royo-Vela \& Casamassima } \\
\text { (2011); Sánchez-Franco et al. } \\
\text { (2012); Habibi et al (2014); Wong } \\
\text { et al. (2018) }\end{array}$ \\
\hline & & Offline & & & Hwang et al. (2018) \\
\hline & & $\begin{array}{c}\text { Online \& } \\
\text { Offline }\end{array}$ & & & Hook et al. (2019) \\
\hline & & \begin{tabular}{|c|} 
Not \\
specified
\end{tabular} & $\begin{array}{l}\text { Algesheimer } \text { et al, (2005); Sung } \text { et } \\
\text { al. (2010); Tsai } \text { et al. (2012) }\end{array}$ & Hedlund (2014) & \\
\hline & \multirow[t]{4}{*}{ 离 } & Online & $\begin{array}{l}\text { Kim et al (2004); Jang et al. } \\
\text { (2008); Kim et al (2008); } \\
\text { Woisetschläger (2008); Hur et al. } \\
\text { (2011); Zhou et al. (2012); Kuo \& } \\
\text { Feng (2013); Jung,Kim \& Kim, } \\
\text { (2014); Munnukka } \text { et al. (2015); } \\
\text { Relling } \text { et al. (2016); Jinghua } \\
\text { Huang (2017); Lim \& Kumar } \\
\text { (2017); Demiray \& Burnaz } \\
\text { (2019); Liao et al. (2019) Vohra } \\
\text { \& Bhardwaj (2019a; 2019b) }\end{array}$ & Jang et al. (2008); Jung et al. (2014) & $\begin{array}{l}\text { Royo-Vela \& Casamassima } \\
\text { (2011); Chen \& Ku (2013); Sierra } \\
\text { et al. } \text { (2016) }\end{array}$ \\
\hline & & Offline & & & \\
\hline & & \begin{tabular}{|c|}
$\begin{array}{c}\text { Online \& } \\
\text { Offline }\end{array}$ \\
\end{tabular} & & & \\
\hline & & \begin{tabular}{|c|}
$\begin{array}{c}\text { Not } \\
\text { specified }\end{array}$ \\
\end{tabular} & Algesheimer et al. (2005) & & \\
\hline
\end{tabular}


Table 2. Summary of the main features of MGWC and The Clan

\begin{tabular}{cc}
\hline MGWC: consumer-run community & The Clan: company-managed community \\
\hline Created in 2002 & Created in 2014 \\
\hline Both offline and online activities and interactions & Both offline and online activities and interactions \\
\hline Moto Guzzi owners & Both owners and fans \\
\hline Membership fee & Free subscription \\
\hline circa 14,000 members worldwide & 14,360 members worldwide \\
\hline
\end{tabular}

Table 3. Description of the sample

\begin{tabular}{|c|c|c|}
\hline Sample Characteristics & The Clan & MGWC \\
\hline Number of respondents & 1,636 & 531 \\
\hline \multicolumn{3}{|l|}{ Gender } \\
\hline Male & $97 \%$ & $97 \%$ \\
\hline Female & $3 \%$ & $3 \%$ \\
\hline Age (average) & 51 & 52 \\
\hline \multicolumn{3}{|l|}{ Nationality } \\
\hline Italy & $52 \%$ & $78 \%$ \\
\hline Other & $48 \%$ & $22 \%$ \\
\hline \multicolumn{3}{|l|}{ First owned Moto Guzzi } \\
\hline Yes & $55 \%$ & $55 \%$ \\
\hline No & $45 \%$ & $45 \%$ \\
\hline
\end{tabular}


Table 4. Measurement model characteristics

\begin{tabular}{|c|c|c|c|c|c|c|}
\hline Constructs and items & $\begin{array}{l}\text { Std. loading } \\
(\mathrm{t}-)\end{array}$ & Mean & SD & CA & CR & AVE \\
\hline $\begin{array}{l}\text { BRAND COMMUNITY INTEGRATION } \\
\text { Consumer-product relationship }\end{array}$ & & & & .84 & .78 & .54 \\
\hline My Guzzi motorcycle is one of my favorite possessions & $.82($ std.) & 4.72 & .633 & & & \\
\hline I love my Guzzi motorcycle & $.76(36.44)$ & 4.68 & 682 & & & \\
\hline I am proud of my Guzzi motorcycle & $.76(36.43)$ & 4.58 & .734 & & & \\
\hline My Guzzi motorcycle is fun to drive & $.68(32.03)$ & 4.62 & .698 & & & \\
\hline Consumer-brand relationship & & & & & & \\
\hline Guzzi is the ultimate sport-utility motorcycle & .72 (std.) & 3.45 & 1.07 & & & \\
\hline I would recommend Guzzi motorcycle to my friends & $.74(30.09)$ & 4.29 & .909 & & & \\
\hline $\begin{array}{l}\text { If I were to replace my Guzzi motorcycle, I would buy another } \\
\text { Guzzi }\end{array}$ & $.63(26.20)$ & 3.60 & 1.29 & & & \\
\hline Guzzi motorcycle is of the highest quality & $.74(30.22)$ & 3.50 & 1.01 & & & \\
\hline Consumer-other owners relationship & & & & & & \\
\hline I feel a sense of kinship with other Guzzi owners & .82 (std.) & 4.19 & .932 & & & \\
\hline I have met wonderful people because of my Guzzi motorcycle & $.72(28.85)$ & 4.00 & 1.11 & & & \\
\hline BRAND COMMUNITY PARTICIPATION & & & & .85 & .84 & .65 \\
\hline $\begin{array}{l}\text { I assist Guzzi community members in finding solutions to their } \\
\text { problems }\end{array}$ & .79 (std.) & 2.97 & 1.18 & & & \\
\hline $\begin{array}{l}\text { I keep up with the latest technical developments in order to make } \\
\text { useful contributions to the Guzzi community }\end{array}$ & $.84(28.55)$ & 3.05 & 1.19 & & & \\
\hline $\begin{array}{l}\text { I am willing to work together with others to improve the } \\
\text { community experience }\end{array}$ & $.77(22.99)$ & 3.44 & 1.15 & & & \\
\hline BRAND COMMUNITY COMMITMENT & & & & .93 & .93 & .82 \\
\hline I really care about the fate of my Guzzi community & .92 (std.) & 3.43 & 1.20 & & & \\
\hline $\begin{array}{l}\text { The relationship I have with my Guzzi community is one I intend } \\
\text { to maintain indefinitely } \\
\text { The relationship I have with my Guzzi community is important to } \\
\text { me }\end{array}$ & $\begin{array}{l}.89(64.69) \\
.90(66.79)\end{array}$ & $\begin{array}{l}3.44 \\
5.07\end{array}$ & $\begin{array}{l}1.21 \\
1.18\end{array}$ & & & \\
\hline
\end{tabular}

Note: $\mathrm{SD}=$ Standard deviation; $\mathrm{CA}=$ Cronbach's alpha; $\mathrm{CR}=$ Composite reliability; AVE = Average variance extracted. std $=$ scaling item

Table 5. Correlations among constructs

\begin{tabular}{llll}
\hline Constructs & $(1)$ & $(2)$ & $(3)$ \\
\hline (1) Brand community commitment & $\mathbf{. 9 0 5}$ & & \\
\hline (2) Brand community participation & .738 & $\mathbf{. 8 0 6}$ & .738 \\
\hline (3) Brand community integration & .548 & .524 & \\
\hline
\end{tabular}

Note: AVE in bold on diagonal 
Table 6. Tests of differences between MGWC and The Clan

\begin{tabular}{lccl}
\hline Constructs & The Clan & MGWC & Diff (t-value) \\
\hline Brand community integration & 2.34 & 2.37 & $.34^{* *}(2.04)$ \\
\hline Customer-to-brand & 3.86 & 3.84 & $.17(.48)$ \\
\hline Customer-to-product & 4.00 & 4.03 & $.28(1.21)$ \\
\hline Customer-to-customer(s) & 3.83 & $\mathbf{3 . 9 4}$ & $\mathbf{. 1 1 * * ( 3 . 3 7 )}$ \\
\hline Brand community participation & 3.10 & 3.20 & $.18^{* * *(6.52)}$ \\
\hline Brand community commitment & 3.25 & 3.51 & $.25^{* * *(7.59)}$ \\
\hline
\end{tabular}

*** $\mathrm{p}<.001 ; * * \mathrm{p}<.005$

Table 7. Test of invariance of path estimates

\begin{tabular}{|c|c|c|c|c|c|c|c|}
\hline & \multicolumn{2}{|c|}{ The Clan } & \multicolumn{2}{|c|}{ MGWC } & \multicolumn{2}{|c|}{ Tests of group differences } & \multirow{2}{*}{$\begin{array}{c}\text { Test of } \\
\text { Invariance }\end{array}$} \\
\hline Relationship & B & z-value & B & z-value & $\Delta \chi^{2}(\mathrm{df}=1)$ & p & \\
\hline BCI $\rightarrow$ BCP. & $.55(.09)$ & $14.80 * *$ & $.59(.16)$ & $9.20 * *$ & .53 & .46 & Invariant \\
\hline $\mathrm{BCP} \rightarrow \mathrm{BCC}$ & $.73(.05)$ & $16.54 * *$ & $.72(.05)$ & $16.48 * *$ & .17 & .68 & Invariant \\
\hline
\end{tabular}

Table 8. Mediation test for both communities

\begin{tabular}{lcccccccc}
\hline & \multicolumn{3}{c}{ The Clan } & \multicolumn{4}{c}{ MGWC } \\
\hline Parameter & Estimate & Lower & Upper & P & Estimate Lower & Upper & P \\
\hline BCI-> BCP -> BCC & .914 & .721 & 1.165 & .001 & .977 & .695 & 1.403 & .001 \\
\hline
\end{tabular}

